DOI: $10.19195 / 0137-1134.114 .37$

\author{
ALEKSANDER MAZIARZ \\ Akademia Leona Koźmińskiego \\ amaziarz@kozminski.edu.pl
}

\title{
NADUŻYCIE POZYCJI DOMINUJĄCEJ PRZEZ WYKONYWANIE PRAW WŁASNOŚCI INTELEKTUALNEJ W PRAWIE KONKURENCJI UNII EUROPEJSKIEJ
}

\begin{abstract}
Abstrakt: Wykonywanie praw własności intelektualnej może stać w sprzeczności z prawem ochrony konkurencji. Rolą tego pierwszego jest bowiem ochrona interesów ich właściciela przed nieuprawnionym wykorzystaniem, co naturalnie prowadzi do utworzenia swego rodzaju monopolu. Prawo zaś ochrony konkurencji ma na celu przeciwdziałać monopolom i tym samym reagować na ograniczenie konkurencji, którego źródłem mogą być także prawa własności intelektualnej. W niniejszym tekście dokonano analizy wykorzystania tego typu praw w celu nadużycia pozycji dominującej przez odmowę udzielenia licencji, odmowę dostępu do urządzenia kluczowego czy zbiorowe zarządzanie prawami własności intelektualnej. W szczególności przyjrzano się przesłankom kwalifikującym wykonywanie praw własności intelektualnej jako przejawu nadużycia pozycji dominującej.
\end{abstract}

Słowa kluczowe: nadużycie pozycji dominującej, odmowa udzielenia licencji, prawa własności intelektualnej

\section{WPROWADZENIE}

Nadużywanie pozycji dominującej jest jedną z najgroźniejszych dla mechanizmu konkurencji praktyk rynkowych. Polega ona na wykorzystaniu siły ekonomicznej przedsiębiorstwa w celu narzucenia niekorzystnych warunków pozostałym uczestnikom rynku. W Traktacie o funkcjonowaniu UE zakazano stosowania tego typu praktyk, jednakże unijny prawodawca nie zawarł w tym dokumencie definicji legalnej nadużycia pozycji dominującej. Zamiast tego wprowadzono przykładowy, otwarty katalog przejawów, które są nadużyciem pozycji dominującej.

Wykonywanie praw własności intelektualnej może być naruszeniem zakazu nadużywania pozycji dominującej. $Z$ jednej strony, można stwierdzić, że celem tych przepisów jest ochrona ich właściciela przed wykorzystaniem przez konkurencję. Z drugiej zaś — jeśli właściciel patentu odmawia udzielenia licencji 
swoim konkurentom, może dojść do ograniczenia konkurencji, w szczególności gdy wejście na określony rynek jest możliwe jedynie z wykorzystaniem takiego patentu. Powoduje to, że naruszeniem prawa konkurencji będzie zachowanie przedsiębiorstwa zgodne z prawem własności intelektualnej. Należy również dodać, że istotą praw własności intelektualnej jest ochrona przed ich nieuprawnionym wykorzystaniem przez konkurencję.

Traktat o funkcjonowaniu Unii Europejskiej nie odnosi się bezpośrednio do praw własności intelektualnej ani do relacji zachodzącej między krajowym prawem chroniącym tego typu własność a unijnymi regułami konkurencji. Ochrona tych praw na poziomie krajowym co do zasady nie narusza więc prawa unijnego, jednakże już w latach 70. Trybunał Sprawiedliwości Unii Europejskiej (dalej: TSUE) stwierdził, że ochrona praw własności intelektualnej na poziomie krajowym może utrudnić swobodę w zakresie przepływu towarów lub ograniczyć konkurencję ${ }^{1}$, w sprawie zaś Parke skonstatował, że patent przyznaje przedsiębiorstwu ochronę na poziomie krajowym, co niestety nie wyklucza wykorzystywania patentów do nadużywania pozycji dominującej².

Celem niniejszej publikacji jest dokonanie analizy poglądów doktryny i orzecznictwa sądów unijnych w celu ustalenia przesłanek zakwalifikowania określonego zachowania polegającego na wykonywaniu praw własności intelektualnej jako przejawu nadużycia pozycji dominującej i w rezultacie ustalenie, jakie są granice wykonywania praw własności intelektualnej.

\section{OSIĄGNIĘCIE POZYCJI DOMINUJĄCEJ WSKUTEK NABYCIA PRAW WŁASNOŚCI INTELEKTUALNEJ}

W odniesieniu do praw własności intelektualnej należy stwierdzić, że umożliwiają one ochronę poczynionych inwestycji określonego przedsiębiorstwa przed konkurentami ${ }^{3}$. Warto podkreślić, że prawa własności intelektualnej nie umożliwiają osiągnięcia przez przedsiębiorstwo monopolu w sensie ekonomicznym. Umożliwiają natomiast wykorzystanie rezultatów pracy przedsiębiorstwa w zakresie własności intelektualnej, dając mu wyłączność na przykład na produkcję określonego produktu ${ }^{4}$. Natomiast to, czy uzyskanie patentu będzie prowadziło do powstania pozycji dominującej, będzie zależało od tego, czy na rynku wystę-

1 Sprawa 40/70, Sirena/Eda, „Zbiór Orzeczeń” (dalej: Zb. Orz.) z 1971 r., s. 69, pkt 4.

2 Sprawa 24/67, Parke, Zb. Orz. z 1968 r., s. 55, pkt 72.

${ }^{3}$ M. Buckley, Licensing intellectual property: Competition and definitions of abuse of a dominant position in the United States and the European Union, „Brooklyn Journal of International Law" 2004, nr 29, s. 798-799.

${ }^{4}$ E. Arezzo, Intellectual property rights at the crossroad between monopolization and abuse of dominant position: American and European approaches compared, ,John Marshall Journal of Computer \& Information Law" 2006, nr 24, s. 494. 
pują substytuty takich produktów, do których wytworzenia nie jest niezbędny ten konkretny patent. Dopiero gdy takich substytutów będzie relatywnie niewiele, po ustaleniu rynku właściwego, może się okazać, że dzięki patentowi przedsiębiorstwo osiągnęło pozycję dominującą lub ją umocniło.

Niemniej jednak osiągnięcie lub umocnienie pozycji dominującej dzięki uzyskaniu patentu nie jest samo przez się nadużyciem tejże pozycji. W szczególności samo uzyskanie licencji wyłącznej nie będzie stanowiło takiego nadużycia. W celu ustalenia, czy wskutek patentu dojdzie do ograniczenia konkurencji przez nadużycie pozycji dominującej, należy przeanalizować wpływ, jaki ma uzyskanie patentu na strukturę konkurencji na danym rynku właściwym, oraz czy umożliwia ona opóźnienie lub zapobieżenie wejściu na rynek konkurentów ${ }^{5}$. W sprawach Sirena $^{6}$ oraz Deutsche Grammophon ${ }^{7}$ Trybunał stwierdził, że do nadużycia pozycji dominującej dojdzie, dopiero gdy dominant będzie w stanie zapobiec efektywnej konkurencji na znacznej części rynku właściwego.

Pozycja dominująca może zostać osiągnięta w wyniku uzyskania przez dominanta takich praw własności intelektualnej, jak licencja wyłączna, znak handlowy czy prawa autorskie. Należy podkreślić, że wykonywanie tego typu praw własności intelektualnej nie jest automatycznie nadużyciem pozycji dominującej, jeżeli ich właścicielem jest dominant. Dopiero stwierdzenie, że wskutek ich wykonywania doszło do ograniczenia konkurencji, będzie przejawem nadużycia pozycji dominującej.

\section{ODMOWA UDZIELENIA LICENCJI JAKO NADUŻYCIE POZYCJI DOMINUJACEJ}

Jedną z najczęściej występujących praktyk będącą przejawem nadużycia pozycji dominującej w odniesieniu do praw własności intelektualnej jest odmowa udzielenia licencji. Do stwierdzenia, czy doszło to stosowania tej praktyki, niezbędne jest ustalenie rynku właściwego. W takich wypadkach rynkiem właściwym będzie rynek produktów lub usług, do których produkcji lub świadczenia niezbędne jest posiadanie licencji. A zatem odmawiając udzielenia licencji, przedsiębiorstwo wyklucza swoich konkurentów z rynku.

Warto podkreślić, że odmowa udzielenia licencji może powodować ograniczenie konkurencji na różnych rynkach relewantnych. Przykładem może tu być sprawa Volvo, w której Trybunał stwierdził, że wykonywanie prawa w zakresie zarejestrowanego wzoru może stanowić nadużycie pozycji dominującej w dwóch przypadkach. Po pierwsze, gdy dominant odmawia dostawy części zamiennych

\footnotetext{
5 Sprawa T-51/89, Tetra Pak, Zb. Orz. z 1990 r., s. II-309, pkt 23.

6 Sprawa 40/70, Sirena, Zb. Orz. z 1971 r., s. 69.

7 Sprawa 78/70, Deutsche Grammophon, Zb. Orz. z 1971 r., s. 487.
} 
niezależnym warsztatom samochodowym. I po drugie, jeśli ustala ceny na nieuczciwym poziomie lub zaprzestaje produkcji części zamiennych, w wypadku gdy określony samochód nadal jest w użyciu ${ }^{8}$. Trybunał uznał więc, że odmowa udzielenia licencji będzie stanowiła przejaw nadużycia pozycji dominującej, gdy dominant zechce ograniczyć konkurencję także na rynkach sąsiadujących. Tego typu praktyka jest szczególnym zagrożeniem dla konkurencji, ponieważ dominant, mający już pozycję dominującą na określonym rynku, będzie chciał ją rozszerzyć właśnie na rynki sąsiadujące. Odmowa udzielenia licencji może również polegać na całkowitym zaprzestaniu produkcji lub świadczenia usług z wykorzystaniem określonego patentu. Tego typu praktyka ma zatem podwójną naturę. Nie dość, że zmusza konkurentów dominanta do zaprzestania określonej działalności gospodarczej przez uniemożliwienie wykorzystania produktów lub usług wytworzonych lub świadczonych z użyciem patentu, to jeszcze wpływa negatywnie na konsumentów, pozbawiając ich na przykład możliwości naprawy zakupionych urządzeń.

Przesłanki dotyczące zakwalifikowania odmowy udzielenia licencji jako przejawu nadużycia pozycji dominującej zostały po raz pierwszy wykształcone w sprawie Magill TV Guide. Sprawa ta dotyczyła odmowy udostępniania przez nadawców telewizyjnych rozkładu emitowanych programów telewizyjnych przedsiębiorstwu, które scalało te informacje i wydawało tygodnik zawierający zbiorczą ramówkę programów telewizyjnych emitowanych w Wielkiej Brytanii. TSUE potwierdził przede wszystkim, że samo posiadanie praw własności intelektualnej nie jest równoznaczne z nadużyciem pozycji dominującej. Aby tak zakwalifikować zachowanie przedsiębiorstwa, niezbędne jest wystąpienie wyjątkowych okoliczności 9 .

TSUE wskazał w tej sprawie trzy przesłanki, których kumulatywne wystąpienie prowadzi do nadużycia pozycji dominującej ${ }^{10}$. Trybunał ustalił, że przedsiębiorstwa nadające programy telewizyjne były jedynym źródłem informacji o nadawanych przez nie programach i na rynku nie było możliwe pozyskanie tych informacji z innych źródeł. A zatem przekazanie takich informacji jest niezbędne dla konkurentów w celu świadczenia określonej usługi. Choć należy dodać, że przesłanka niezbędności jest niejasna i sam TSUE wskazał, że należy ona do interpretacji przez sądy krajowe poprzez analizę zebranego w sprawie materiału dowodowego ${ }^{11}$.

Odmowa udostępnienia tych informacji uniemożliwiła stworzenie nowego produktu — tym samym stworzyła barierę wejścia na rynek tygodnikowi zawiera-

8 Sprawa 238/87, Volvo, Zb. Orz. z 1998 r., s. 6211.

9 Połączone sprawy C-241/91 P i C-242/91 P, Magill, Zb. Orz. z 1995 r., s. I-743.

${ }^{10}$ Chociaż pojawiają się wątpliwości, czy te przesłanki muszą być spełnione kumulatywnie; zob. np. A. Shah, The abuse of dominant position under article 82 of the Treaty of the European Community: Impact on licensing of intellectual property rights, „Chicago-Kent Journal of Intellectual Property" 2003, nr 3, s. 41 n.

11 C. Waelde et al., Contemporary Intellectual Property: Law and Policy, Oxford 2013, s. 890. 
jącemu zbiorcze zestawienie ramówki programów emitowanych przez wszystkich trzech nadawców). Co więcej, nie było żadnego obiektywnego uzasadnienia odmowy udostępnienia tego typu informacji przez nadawców telewizyjnych. TSUE słusznie uznał, że w taki sposób przedsiębiorstwa odmawiające udostępnienia informacji o swoich programach rozciągnęły własną pozycję dominującą na rynki sąsiednie - tygodniowych rozkładów audycji telewizyjnych, na które było zapotrzebowanie ze strony konsumentów ${ }^{12}$.

Ważne jest przy tym, że odmowa udostępnienia informacji została dokonana przy nieoferowaniu takiego produktu na rynku, tym samym TSUE wziął pod uwagę, że zachowanie takie szkodzi także konsumentom, pozbawiając ich możliwości wykorzystania określonego produktu. Warto przy tym zaznaczyć, że skoro tygodniowe zestawienia programów nie były oferowane na rynku, to odmowa udzielenia informacji nie stanowiłaby uszczuplenia praw własności intelektualnej nadawców telewizyjnych. Niemniej jednak TSUE wskazał, że przedsiębiorstwa mogą pobierać opłaty licencyjne za udostępnianie informacji o emitowanych programach i właśnie w ten sposób zapewniona była ochrona ich praw własności intelektualnej.

Wskazane przesłanki zostały następnie rozwinięte w sprawie IMS Health ${ }^{13}$ Sąd UE potwierdził, że wymienione cztery przesłanki to wyjątkowe okoliczności, w których odmowa udzielenia licencji stanowić będzie nadużycie pozycji dominującej. Należy przy tym zaznaczyć, że sąd UE, uznając wykształcone uprzednio przesłanki, stwierdził, że z uwagi na wyjątkowe okoliczności danej sprawy mogą być one inne. Tym samym sąd UE podkreślił, że katalog tych przesłanek nie jest zamknięty ${ }^{14}$. Jednakże orzeczenie to nie daje jednoznacznej odpowiedzi, które z okoliczności spraw związanych z własnością intelektualną mogą być „wyjątkowe"15.

Szczególną uwagę sąd UE zwrócił jednak na przesłankę uniemożliwienia wprowadzenia na rynek nowego produktu. Sam termin ,nowy produkt” nie został niestety wyjaśniony, co powoduje, że nie wiadomo, czy chodzi tu o produkt dopiero opracowywany, czy taki, który próbuje się już wprowadzić na rynek ${ }^{16}$. W omawianym orzeczeniu wskazano również sposób bilansowania prawa własności intelektualnej i prawa ochrony konkurencji. Sąd UE stwierdził, że prawo konkurencji przeważa w wypadku, gdy wykonywanie praw własności intelektualnej

12 Połączone sprawy C-241/91 P i C-242/91 P, Magill, Zb. Orz. z 1995 r., s. I-743.

13 Sprawa C-481/01, IMS Health, Zb. Orz. z 2001 r., s. II-3193.

14 H. Ćatović, Refusal to License Intellectual Property Rights as Abuse of Dominant Position in EU Competition Law The Implications of the Huawei Judgment, s. 48, http://www.konkurrensverket. se/globalassets/forskning/uppsatser/uppsats-2016_haris-catovic.pdf (dostęp: 19.12.2017).

15 E. Derclaye, Abuses of dominant position and intellectual property rights: A suggestion to reconcile the community courts case law, „World Competition” 2003, nr 4, s. $702 \mathrm{n}$.

16 J. Houdijk, The IMS Health ruling: Some thoughts on its significance for legal practice and its consequences for future cases such as Microsoft, „European Business Organization Law Review” 2005, nr 5, s. 487. 
ogranicza możliwość rozwoju na rynku sąsiednim, co szkodzi konsumentom ${ }^{17}$. To właśnie wprowadzenie nowych produktów na rynek jest istotną przesłanką wskazującą, czy wykonywanie prawa własności intelektualnej będzie przejawem nadużycia pozycji dominującej. Warto przy tym dodać, że sąd UE niejako uznał, że przesłanka odnosząca się do nowego produktu nie będzie spełniona, jeśli na rynku znajdują się już substytucyjne produkty. A zatem, jeżeli cechy nowego produktu są powielone przez inne, już oferowane na rynku, dominant może odmówić udzielenia licencji. W przeciwnym razie konkurenci dominanta mogliby w łatwy sposób „,imitować” jego produkt, żądając udzielenia licencji. Wówczas o tym, czy dany produkt jest już oferowany na rynku, może zadecydować właśnie to, czy jest on postrzegany przez konsumentów jako substytucyjny.

\section{ZAPOBIEGANIE INTEROPERACYJNOŚCI}

Szczególną formą odmowy udzielenia licencji jest taka odmowa uniemożliwiająca interoperacyjność systemów informatycznych. Ma to miejsce, gdy niezbędna jest wymiana danych między systemami informatycznymi stworzonymi przez różnych producentów, z których jeden odmawia przekazania informacji niezbędnych do wspólnego i prawidłowego działania programów informatycznych. Wspomniana praktyka w szczególności zajdzie w wypadku, gdy rynek zdominowany jest przez jednego dostawcę systemów informatycznych, który przez odmowę udostępnienia informacji o swoim systemie blokuje możliwość wejścia na ten rynek swoim konkurentom.

Pierwsza tego typu sprawa dotyczyła producenta sprzętu komputerowego IBM, który odmówił swoim konkurentom udzielenia informacji o stosowanych protokołach, przez co uniemożliwił im dostarczenie konkurencyjnego oprogramowania. Na podstawie ugody zawartej pomiędzy IBM a Komisją Europejską ten pierwszy zobowiązał się do udostępnienia wszelkich informacji niezbędnych jego konkurentom do wyprodukowania takiego oprogramowania w zamian za odstąpienie od wszczęcia postępowania antymonopolowego ${ }^{18}$.

Jedną z najważniejszych spraw dotyczących zakwalifikowania odmowy udzielenia licencji jako przejawu nadużycia pozycji dominującej przez uniemożliwienie interoperacyjności była sprawa Microsoft. Dotyczyła ona rynku systemów operacyjnych dla sieci informatycznych. Warto odnotować, że Microsoft wszedł na rynek, na którym funkcjonowały już inne systemy operacyjne, a po wpłynięciu do Komisji Europejskiej skargi o naruszenie zakazu nadużywania pozycji dominującej poprzez odmowę udzielenia licencji na ten rynek wszedł system Linux, oczywiście nie mając licencji od Microsoftu. Temu ostatniemu zarzucono,

17 Sprawa C-481/01, IMS Health, Zb. Orz. z 2001 r., s. II-3193, pkt 48.

18 Szesnasty raport o polityce konkurencji, Bruksela-Luksemburg 1984. 
że dopuścił się nadużycia pozycji dominującej poprzez odmowę udostępnienia wystarczających informacji o interfejsie swoim konkurentom, które umożliwiłyby stworzenie oprogramowania kompatybilnego z systemami Microsoftu.

Bardzo istotnym ustaleniem w tej sprawie było to, że Komisja Europejska nie ma określonego katalogu wyjątkowych okoliczności, które muszą zostać zastosowane do oceny, czy odmowa udzielenia licencji stanowi przejaw nadużycia pozycji dominującej ${ }^{19}$. Oznacza to, że przesłanki wykształcone w poprzednich sprawach nie są jednymi, które należy brać pod uwagę przy ocenie tego typu zachowań. W tej sprawie uznano, że wyjątkowymi okolicznościami świadczącymi o dopuszczeniu się nadużycia pozycji dominującej było to, iż Microsoft przyjął praktykę odmowy udostępniania informacji konkurentom, uniemożliwiając interoperacyjność, a nawet jeżeli częściowo dokonał takiego udostępnienia, to nie czynił tego w odniesieniu do nowych systemów operacyjnych, co spowodowało ryzyko wyeliminowania konkurentów rynków systemów operacyjnych dla sieci komputerowych i ograniczyło postęp technologiczny, albowiem konkurenci nie byli zainteresowani wprowadzaniem konkurencyjnych systemów operacyjnych, z których korzystałoby bardzo mało użytkowników ${ }^{20}$.

Ważne dla oceny, czy odmowa udzielenia licencji stanowi nadużycie pozycji dominującej, było ustalenie dotyczące ograniczenia wprowadzenia na rynek nowego produktu. O ile w poprzednich sprawach TSUE wskazywał, że odmowa ta uniemożliwi produkcję określonego produktu, o tyle w sprawie Microsoft stwierdzono, że ograniczenie w postępie technologicznym prowadzi do wystąpienia negatywnych skutków dla konsumentów ${ }^{21}$, chociaż nie dokonano analizy, czy udoskonalenie techniczne już funkcjonujących na rynku systemów doprowadzi w przyszłości do powstania nowych programów ${ }^{22}$. Ograniczenie to nie było utożsamiane z uniemożliwieniem wprowadzenia na rynek nowego produktu, ale było postrzegane jako ograniczenie innowacji na całym rynku oprogramowania komputerowego kompatybilnego z systemami Microsoftu. Choć można też poddać krytyce, czy organa antymonopolowe wyposażone są w odpowiednie narzędzia umożliwiające badanie całego sektora przemysłu pod kątem innowacyjności ${ }^{23}$, ustalenie to było w tej sprawie kluczowe.

Natomiast zdaniem Komisji Europejskiej należy nałożyć na dominanta obowiązek udzielenia licencji w wypadku, gdy wyjątkowe okoliczności danej sprawy

19 I. Bael, J. Bellis, Competition Law of the European Community, The Hague 2010, s. 851.

20 Decyzja Komisji Europejskiej COMP/C-3/37.792 Microsoft, 24.3-2004, pkt 569, 577, $701,781$.

21 Ibidem, pkt 647.

22 A. Andreangeli, Case T-201/04. Microsoft v. Commission: Judgment of the Grand Chamber of the Court of First Instance of 17 September 2007, „Common Market Law Review” 2008, nr 45, s. 863-894.

23 C. Ritter, Refusal to deal and essential facilities: Does intellectual property require special deference compared to tangible property?, „World Competition” 2005, $\mathrm{nr} 3$, s. 281-289. 
wskazują na konieczność ochrony interesu publicznego, jakim jest zapobieganie wystąpieniu negatywnych dla konsumentów skutków ${ }^{24}$.

\section{PRAWA WŁASNOŚCI INTELEKTUALNEJ JAKO URZĄDZENIE KLUCZOWE}

Prawo konkurencji UE nie zawiera definicji legalnej urządzenia kluczowego. Termin ten po raz pierwszy pojawił się w orzecznictwie TSUE w sprawie Oscar Bronner. TSUE stwierdził wówczas, że urządzeniem kluczowym będzie takie urządzenie, które jest niezbędne do prowadzenia działalności gospodarczej i jednocześnie nie jest możliwe zduplikowanie go ze względu na techniczne, prawne lub ekonomiczne przeszkody. Typowymi urządzeniami kluczowymi są drogi, mosty czy rurociągi, jednak może być nimi również infrastruktura o charakterze niematerialnym ${ }^{25}$.

Nadużyciem pozycji dominującej będzie więc odmowa zagwarantowania dostępu przez dominanta do urządzenia kluczowego, czego skutkiem będzie całkowite wyeliminowanie konkurencji z danego rynku oraz powstanie barier dostępu do tego rynku. Tak zwana doktryna urządzeń kluczowych ${ }^{26}$ jest zatem odstępstwem od zasady, że samo utrzymywanie pozycji dominującej nie stanowi naruszenia prawa konkurencji, chyba że dominant podejmie takie zachowania, których celem jest ograniczenie konkurencji ${ }^{27}$.

Jedną z pierwszych spraw, w których TSUE zmierzył się z zastosowaniem doktryny urządzeń kluczowych do zachowania dominanta polegającego na wykonywaniu praw własności intelektualnej, była sprawa Ladbroke ${ }^{28}$. Przedsiębiorstwo dysponujące prawami wyłącznymi na transmisję z wyścigów konnych na terenie Francji odmówiło udzielenia zgody na retransmisję belgijskiej agencji bukmacherskiej. TSUE stwierdził, że naruszeniem zakazu nadużywania pozycji dominującej będzie odmowa udostępnienia praw własności intelektualnej niezbędnych do prowadzenia działalności gospodarczej. Uznano, że skoro wyścigi te były transmitowane, to umożliwia to funkcjonowanie przedsiębiorstwa bukmacherskiego, a sama

24 G. Monti, EC Competition Law, Cambridge 2007, s. 230.

$25 \mathrm{~V}$. Korah, The interface between intellectual property and antitrust: The European experience, „Antitrust Law Journal” 2002, nr 3, s. 801-839.

${ }^{26}$ Doktryna essential facilities wywodzi się ze Stanów Zjednoczonych. Określenia tego użyto po raz pierwszy w sprawie Terminal Railroad z 1912 r., w której Sąd Najwyższy Stanów Zjednoczonych rozpoznawał, czy doszło do naruszenia konkurencji przez przejęcie urządzeń infrastruktury kolejowej w stanie Illinois, aczkolwiek w tej sprawie sąd nie użył pojęcia essential facility, lecz terminal facility.

${ }^{27}$ H. Hovenkamp, M.D. Janis, M.A. Lemley, IP and antitrust: An analysis of antitrust principles applied to intellectual property law, [w:] ABA Antitrust \& Intellectual Property: Competition and Innovation in High-Tech Industries, Chicago 2002, s. 13-21.

28 Sprawa T-74/92, Ladbroke Racing v. Commission (Ladbroke I), Zb. Orz. z 1995 r., s. II-115. 
retransmisja nie jest niezbędna do prowadzenia tej działalności ${ }^{29}$. Orzeczenie owo potwierdza, że to okoliczności danej sprawy decydują o uznaniu danego zachowania przedsiębiorstwa za nadużycie pozycji dominującej oraz że prawa własności intelektualnej mogą być niezbędne do prowadzenia działalności gospodarczej i przez to można je zakwalifikować jako urządzenie kluczowe.

Za urządzenie kluczowe można też poczytać usługi raportowania danych hurtowych sprzedaży leków, których udostępnienia przedsiębiorstwo IMS Health odmówiło swoim konkurentom, powołując się na prawa autorskie. TSUE nałożył na IMS obowiązek udzielenia licencji konkurentom, uznając, że jest ona niezbędna do prowadzenia działalności gospodarczej przez konkurentów i z tego powodu stanowi urządzenie kluczowe $\mathrm{e}^{30}$.

\section{WYKONYWANIE PRAW W ZAKRESIE ZBIOROWEGO ZARZĄDZANIA PRAWAMI AUTORSKIMI}

Zbiorowe zarządzanie prawami autorskimi uregulowane jest odmiennie w każdym państwie członkowskim ${ }^{31}$. Nie oznacza to jednak, że przedsiębiorstwa zarządzające takimi prawami mogą wykorzystywać swoją pozycję ze szkodą dla konkurencji. Cechą zbiorowego zarządzania prawami autorskimi jest to, że często na rynku występuje zaledwie kilka takich przedsiębiorstw, co może powodować, iż będą one miały pozycję dominującą. W sprawie Greenwitch TSUE stwierdził, że przedsiębiorstwa zbiorowego zarządzania prawami autorskimi działają co prawda na terenie jednego państwa członkowskiego, jednakże mogą one dopuścić się takiego zachowania, którego celem będzie podział wspólnego rynku i tym samym ograniczenie swobody przepływu usług ${ }^{32}$. Dlatego też nawet zachowanie przedsiębiorstwa, które z uwagi na ustawodawstwo krajowe nie może przekraczać granic danego państwa członkowskiego, może stanowić przejaw nadużycia pozycji dominującej, jeżeli jego celem jest przywrócenie granic między państwami przez stworzenie barier wejściu lub wyjściu z rynku krajowego.

29 Ibidem.

$30 \mathrm{~J}$. Turney, Defining the limits of the EU essential facilities doctrine on intellectual property rights: The primacy of securing optimal innovation, „Northwestern Journal of Technology and Intellectual Property" 2005, nr 3, s. 118.

31 Na podstawie dyrektywy 2014/26/UE w sprawie zbiorowego zarządzania prawami autorskimi i prawami pokrewnymi oraz udzielania licencji wieloterytorialnych dotyczących praw do utworów muzycznych do użytku online na rynku wewnętrznym wprowadzono harmonizację zbiorowego zarządzania prawami autorskimi na terenie UE. Celami tej dyrektywy były przede wszystkim zwiększenie przejrzystości działania przedsiębiorstw zajmujących się zbiorowym zarządzaniem prawami autorskimi, poprawa działania tych przedsiębiorstw oraz zagwarantowanie twórcom kontroli w zakresie ochrony ich praw.

32 Sprawa 22/79, Greenwitch/SACEM, Zb. Orz. z 1979 r., s. 3275, pkt 12-13. 
Na podstawie orzecznictwa TSUE należy skonstatować, że nadużyciem pozycji dominującej będzie odmowa objęcia usługami takiego przedsiębiorstwa artysty zagranicznego, który nie jest rezydentem danego państwa członkowskiego. Takie zachowanie powoduje bowiem utratę możliwości wypłaty tantiem artystom zagranicznym ${ }^{33}$.

Trzeba także stwierdzić, że nadużyciem pozycji dominującej będzie wykorzystanie siły rynkowej do nałożenia na artystów, których prawami takie przedsiębiorstwo zarządza, zobowiązań niebędących niezbędnymi do zbiorowego zarządzania prawami autorskimi. Przykładem może być nałożenie obowiązku do objęcia zbiorowym zarządzaniem przez przedsiębiorstwo wszystkich utworów danego artysty, zarówno wytworzonych obecnie, jak i w przyszłości, na wszystkich polach eksploatacji ${ }^{34}$. Nadużyciem pozycji dominującej będzie również takie nakładanie na określone podmioty opłat przez przedsiębiorstwo zbiorowego zarządzania prawami autorskimi w danym państwie członkowskim, które są znacząco wyższe niż w innych krajach członkowskich, i jednocześnie nie ma żadnego obiektywnego uzasadnienia stosowania takich wygórowanych cen $^{35}$.

\section{PODSUMOWANIE}

Wykonywanie praw własności intelektualnej niewątpliwie może doprowadzić do nadużycia pozycji dominującej. Oznacza to, że nawet jeżeli przedsiębiorstwo dokona znacznych inwestycji i dzięki nim osiągnie przewagę konkurencyjną na rynku, będzie musiało podzielić się z konkurencją swoimi rozwiązaniami lub prawami autorskimi. O ile taka sytuacja z punktu widzenia prawa konkurencji jest zrozumiała, ponieważ przeciwdziała zamknięciu dostępu do rynku dla konkurentów, o tyle już z punktu widzenia praw własności intelektualnej może budzić wątpliwości. To właśnie aby taką przewagę osiągnąć, przedsiębiorstwa inwestują $\mathrm{w}$ innowacje i tym samym ponoszą ryzyko wprowadzenia na rynek nowego produktu lub usługi. Tym samym ich sukces rynkowy może powodować konieczność udostępnienia na przykład nowej technologii konkurentom, którzy nie ponieśli żadnego ryzyka związanego z innowacją. Można więc uznać, że w ten sposób przedsiębiorstwo, które odniosło sukces i następnie, aby uniknąć zarzutu nadużycia pozycji dominującej, podzieliło się swoimi nowymi rozwiązaniami z konkurentami, nie będzie już zainteresowane dokonywaniem innowacji w przyszłości ${ }^{36}$. W niektórych przypadkach może zatem dojść do obowiązku udzielenia

33 Sprawa 7/82, GVL, Zb. Orz. z 1983 r., s. 483, pkt 51-56.

34 Sprawa 127/73, BRT/SABAM, Zb. Orz. z 1974 r., s. 313., pkt 12, 15.

35 Połączone sprawy C-110/88 i C-241/88, Lucazeau przeciwko SACEM, Zb. Orz. z 1989 r., s. 2811.

36 Podobnie V. Korah, The Ladbroke saga, „European Competition Law Review” 1998, nr 3, s. $169-174$ 
licencji. Tak też postąpił TSUE w sprawie Magill, nakazując udzielenie licencji trzem przedsiębiorstwom. Jednak otwarta pozostaje kwestia, jak szeroko dominant powinien udostępnić konkurentom swoje prawa własności intelektualnej, aby nie ciążył na nim zarzut nadużycia tejże pozycji. Skoro samo utrzymywanie pozycji dominującej nie jest zakazane, to tym samym zobowiązanie dominanta do udzielenia licencji spowoduje $\mathrm{w}$ istocie utratę części rynku i osłabienie jego pozycji dominującej.

Dokonując analizy orzecznictwa TSUE, trudno określić uniwersalne przesłanki zakwalifikowania zachowania polegającego na wykonywaniu praw własności intelektualnej jako przejawu nadużycia pozycji dominującej. Wynika to z bardzo skomplikowanych stanów faktycznych, w których różnego rodzaju prawa własności intelektualnej były wykorzystywane do ograniczenia konkurencji. Zasadne jest więc potwierdzenie stanowiska TSUE, że przesłanki stosowania takiej praktyki będą zależeć przede wszystkim od okoliczności faktycznych danej sprawy i w rezultacie mogą być inne w każdej sprawie.

\title{
ABUSE OF DOMINANT POSITION IN RELATION TO INTELLECTUAL PROPERTY RIGHTS IN EU COMPETITION LAW
}

\author{
Summary
}

The exercise of intellectual property rights may be contrary to the competition law. The role of first mentioned law is to protect the interests of their owners from unauthorized use by competitors, which naturally leads to the creation form of monopoly. Competition law is aimed at countering monopolies and thereby responding to the restriction of competition, which may also be a result of exercise of intellectual property rights. The publication analyses in what way such rights can abuse dominant position. In particular it will focus on such practices as refusing to grant a license, denying access to a key device or abusing collective management of intellectual property rights. The publication will try to determine conditions which qualify exercise of intellectual property rights as abuse of dominant position.

Keywords: abuse of dominant position, refusal to license, intellectual property rights

\section{BIBLIOGRAFIA}

Andreangeli A., Case T-201/04. Microsoft v. Commission: Judgment of the Grand Chamber of the Court of First Instance of 17 September 2007, „Common Market Law Review” 2008, nr 45.

Arezzo E., Intellectual property rights at the crossroad between monopolization and abuse of dominant position: American and European approaches compared, „John Marshall Journal of Computer \& Information Law" 2006, nr 24.

Bael I., Bellis J., Competition Law of the European Community, The Hague 2010.

Buckley M., Licensing intellectual property: Competition and definitions of abuse of a dominant position in the United States and the European Union, „Brooklyn Journal of International Law" 2004, nr 29.

Przegląd Prawa i Administracji 114, 2018

(C) for this edition by CNS 
Ćatović H., Refusal to License Intellectual Property Rights as Abuse of Dominant Position in EU Competition Law The Implications of the Huawei Judgment, http://www.konkurrensverket. se/globalassets/forskning/uppsatser/uppsats-2016_haris-catovic.pdf.

Derclaye E., Abuses of dominant position and intellectual property rights: A suggestion to reconcile the community courts case law, „World Competition” 2003, nr 4.

Houdijk J., The IMS/Health ruling: Some thoughts on its significance for legal practice and its consequences for future cases such as Microsoft, „European Business Organization Law Review" 2005, nr 5.

Hovenkamp H., Janis M.D., Lemley M.A., IP and antitrust: An analysis of antitrust principles applied to intellectual property law, [w:] ABA Antitrust \& Intellectual Property: Competition and Innovation in High-Tech Industries, Chicago 2002.

Korah V., The interface between intellectual property and antitrust: The European experience, „Antitrust Law Journal” 2002, nr 3.

Korah V., The Ladbroke saga, „European Competition Law Review” 1998, nr 3.

Monti G., EC Competition Law, Cambridge 2007.

Ritter C., Refusal to deal and essential facilities: Does intellectual property require special deference compared to tangible property?, „World Competition” 2005, nr 3.

Shah A., The abuse of dominant position under article 82 of the Treaty of the European Community: Impact on licensing of intellectual property rights, „Chicago-Kent Journal of Intellectual Property" 2003, nr 3.

Turney J., Defining the limits of the EU essential facilities doctrine on intellectual property rights: The primacy of securing optimal innovation, „Northwestern Journal of Technology and Intellectual Property" 2005, nr 3.

Waelde C. et al., Contemporary Intellectual Property: Law and Policy, Oxford 2013. 